J. Lake Sci. (湖泊科学), 2007,19(2):204-211

http:// www. jlakes. org. E-mail: jlakes@ niglas. ac.cn

(c) 2007 by Journal of Lake Sciences

\title{
从东江调水后契爷石水库的水质和浮游植物群落结构特征
}

\author{
欧阳昊, 韩博平 ${ }^{* *}$
}

(暨南大学水生生物研究所,广州 510632)

\begin{abstract}
摘 要: 契爷石水库是广东省东莞市的一座中型供水水库, 为富营养化水体. 为改善该水库水质, 2002 年 10 月开始从东江 调水, 以满足供水的水量和水质要求. 在调水后的两年期间, 对水文、水质和浮游植物种类和数量进行了调查. 本文将调查 结果与以往 (2000 年) 调查数据进行了对比, 分析了调水后该水库水质和浮游植物的特点和调水对水质的影响. 调水直接 导致 TP 浓度显著下降, 丰水期的 TN 浓度有一定下降, 但调水并没显著降低枯水期 TN 的浓度. 调水后, 丰水期水体的叶 绿素 $\mathrm{a}$ 浓度有明显的增加, 枯水期叶绿素 $\mathrm{a}$ 浓度大大低于调水前. 与调水前相比, 调水后浮游植物种类数有明显增加, 特 别是绿藻种类, 蓝藻中的假鱼腥藻和针状蓝纤维藻仍为浮游植物优势种, 但硅藻中的短小曲壳藻和针杆藻等成为新的优 势种, 裸藻的数量大为减少.
\end{abstract}

关键词: 调水; 水质; 浮游植物群落; 契爷石水库

\section{Water quality and phytoplankton community in the Qiyeshi Reservoir after water diversion from Dongjiang River}

\author{
OUYANG Hao, HAN Boping
}

(Institute of Hydrobiology, Jinan University, Guangzhou 510632, P. R. China)

\begin{abstract}
The Qiyeshi Reservoir, located in Dongguan City, Guangdong Province, is a medium sized reservoir for drinking-water supply. To meet the demand in water quantity and water quality, the water was diverged from Dongiiang River to the reservoir in October 2002. In order to understand the ecological effect of this water diversion, the hydrologic conditions, water quality and the distribution of phytoplankton assemblage were surveyed from 2003 to 2004. The results showed that the Total phosphorus (TP) concentration was remarkably diluted by water flushing, however, total nitrogen concentration ( TN) only decreased in the flood seasons. In flood seasons, the improvement of light condition in water favored phytoplankton growth, leading to the increase in phytoplankton abundance and biomass. In dry seasons, phytoplankton abundance decreased largely due to the dilution by huge amount of transported water into the reservoir. The water diversion also had an impact on species composition of phytoplankton. The species number increased notably, especially for chlorophyta. Pseudoanabaena sp. and Dactylococcopsis continued to be the dominated species, however, Achnanthaceae and Synedra sp. became one of the dominated species, and the abundance of Phacus stokesi and Trachelomonas sp. decreased remarkably.
\end{abstract}

Keywords: Water diversion; water quality; phytoplankton community; Qiyeshi Reservoir

水库是一种半人工水体,在很多缺水地区,已成为主要的供水水源. 随着人类活动的加剧,很多供水水 库出现了富营养化问题, 特别是城市周边地区的中小型水库的富营养化程度普遍较高 ${ }^{[1]}$. 广东省是我国水 库主要的分布地区之一,目前水库供水量的 $70 \%$ 是通过中小型水库供水实现, 对中小型供水水库的管理得 到广泛的重视. 在改善水质的方法中, 提调清水人库通常被认为是见效最快的方法. 调清水人库可降低水库 中营养盐水平 ${ }^{[2]}$, 提高水体的交换能力, 降低水库底部的缺氧风险 ${ }^{[3-5]}$, 减少二次污染. 调水人库已在不同

* 教育部骨干教师基金和广东省水文局重点项目.2006-04-24 收稿;2006-06-06 收修改稿. 欧阳吴, 男,1982 年 生,硕士研究生.

** 通迅作者: E-mail: tbphan@jnu. edu.cn. 
的水体中得到运用, 但目前对这种方法的实际效果还缺少系统的研究与评估. 在多数情况下, 调清水人库能 有效地改善水质, 但对不同水体, 其改善水质的程度依赖于水库生态系统本身的特征和对调水的管理 模式 ${ }^{[6]}$.

契爷石水库位于广东省东莞市清溪镇, 是一座中型城市供水水库. 总库容 $10 \times 10^{6} \mathrm{~m}^{3}$, 集水面积 17.6 $\mathrm{km}^{2}$, 最大库容时平均水深 $4.4 \mathrm{~m}$, 供水人口 $0.27 \times 10^{6}$. 建库初期, 水库主要用于农业灌溉, 但 20 世纪 90 年 代后, 由于水质性缺水, 该水库成为城镇主要供水水源. 根据 2000 年的调查, 该水库为富营养化水体, 总磷 的浓度较高, 在枯水期和丰水期均超过 $0.1 \mathrm{mg} / \mathrm{L}$, TN 浓度大于 $1 \mathrm{mg} / \mathrm{L}$, 叶绿素 a 浓度的最大值为 $32 \mathrm{mg} /$ $\mathrm{m}^{3}$, 透明度在 0.4-0.8 $\mathrm{m}$ 之间, 营养状态指数在 50 左右, 浮游植物以蓝藻中的假鱼腥藻和针状蓝纤维藻为 优势种, 同时有大量裸藻出现 ${ }^{[1,7]}$. 为改善水质和增加供水量, 从 2002 年 10 月开始通过密封管道从东江调 水人库. 为了解调水后水库水质的状况, 于 2003 年和 2004 年对该水库进行 9 次调查. 本文报道了该水库调 水后的水质和浮游植物的特征, 并与我们 2000 年的调查数据进行了比较, 探讨了调水对水库水质和浮游植 物群落的影响.

\section{1 材料与方法}

\section{1 采样点设置与采样时间}

尽管该水库的总库容达 $10 \times 10^{6} \mathrm{~m}^{3}$, 而平时的蓄水量平均为 $6 \times 10^{6} \mathrm{~m}^{3}$, 最低不足 $3.5 \times 10^{6} \mathrm{~m}^{3}$, 实际库 容小, 水位变化大. 由于大坝处水域的水质和浮游植物变化相对受调水影响明显, 采样点设在水库大坝 (S1) 处, 同时考虑到实际水位的变化和垂直采样的可操作性, 没有分层采样 (图 1). 2003 年 7、9、12 月及 2004 年 $2 、 4 、 6 、 8 、 10 、 12$ 月对采样点进行采样.

\section{2 采样与分析方法}

$\mathrm{TN} 、 \mathrm{TP}$ 试验用水用 $250 \mathrm{ml}$ 的白色玻璃瓶盛装; $\mathrm{NO}_{3}-\mathrm{N}$ 、 $\mathrm{NO}_{2}-\mathrm{N} 、 \mathrm{NH}_{4}-\mathrm{N} 、 \mathrm{PO}_{4}-\mathrm{P}$ 试验用水经过 $0.45 \mu \mathrm{m}$ 的纤维滤膜抽滤 后盛装在棕色的 $500 \mathrm{ml}$ 的玻璃瓶中, 带回实验室后在 $24 \mathrm{~h}$ 内处 理和测定. 叶绿素 a 用 $0.45 \mu \mathrm{m}$ 的纤维滤膜抽滤 $500 \mathrm{ml}$, 反复冻 融 - 浸提, 运用改进的丙酮萃取方法进行测定 ${ }^{[8]}$. 浮游植物定 量样品在表层 $0.5 \mathrm{~m}$ 处采取 $1 \mathrm{~L}$ 水样, 用福尔马林固定, 浓度为 $5 \%$, 在实验室浓缩沉淀; 浮游植物定性样品用 25 号浮游生物网 $(64 \mu \mathrm{m})$, 在不同方向进行拖网, 同样用福尔马林固定 ${ }^{[9]}$, 浓度 为 $5 \%$. 浮游植物定性、定量样品均在 OLYMPUS 显微镜下进行 鉴定和计数. 藻类生物体积根据各藻类相近几何形状的体积公 式计算 ${ }^{[10,11]}$, 假定浮游植物藻类的密度为 $1 \mathrm{~g} / \mathrm{cm}^{3}$, 计算浮游植 物生物量.

\section{2 结果与分析}

\section{1 水库的水文动态}

契爷石水库在 2003 年和 2004 年丰水期 (4 - - 月 ) 降雨量

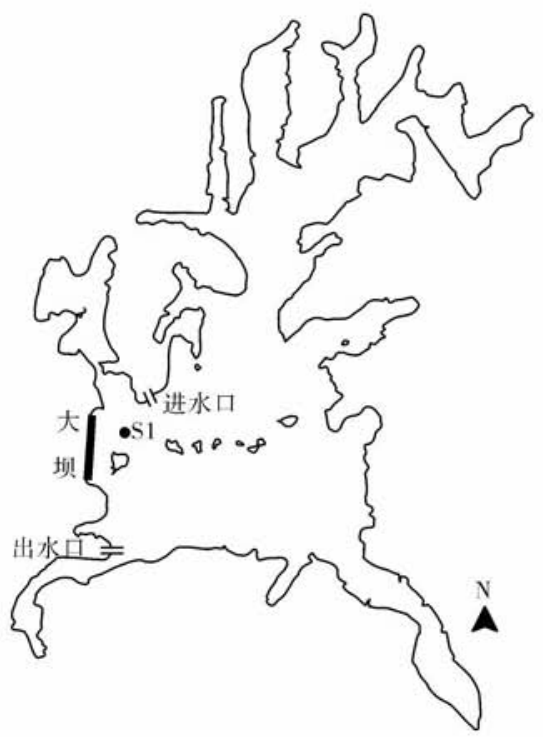

图 1 契爷石水库采样点 相对较高, 每月平均为 $176 \mathrm{~mm}$, 枯水期降雨量较低, 每月降雨量 Fig. 1 The Sampling site in Qiyeshi Reservoir 一般低于 $30 \mathrm{~mm}$.

调水主要发生在枯水期,其中 $10-12$ 月的调水量最大,每月平均达 $150 \times 10^{4} \mathrm{~m}^{3}$, 丰水期降水量大而调 人的水量很少, $2-9$ 月的每月调水量一般低于 $50 \times 10^{4} \mathrm{~m}^{3}$ (图 2). 2003 年与 2004 年的调水量略有差别, 2004 年的丰水期有一定调水. 在枯水期初期, 从东江大量调水进人水库, 以满足枯水期供水需求, 导致枯水 期水库库容高于丰水期 (图 3). 水库调水以后, 水库供水能力增加, 供水量稳定, 每月出库流量均保持在 170 $\times 10^{4} \mathrm{~m}^{3}$ 左右. 与 2000 年相比,由于降雨减少和供水量的增加, 2003 年 -2004 年丰水期的库容有明显的 下降. 


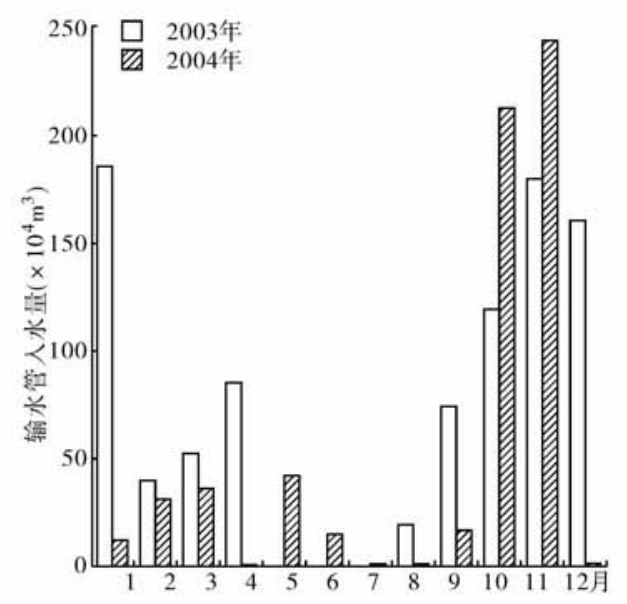

图 2 调水人库水量

Fig. 2 Transported water volume into

Qiyeshi Reservoir in 2003 and 2004

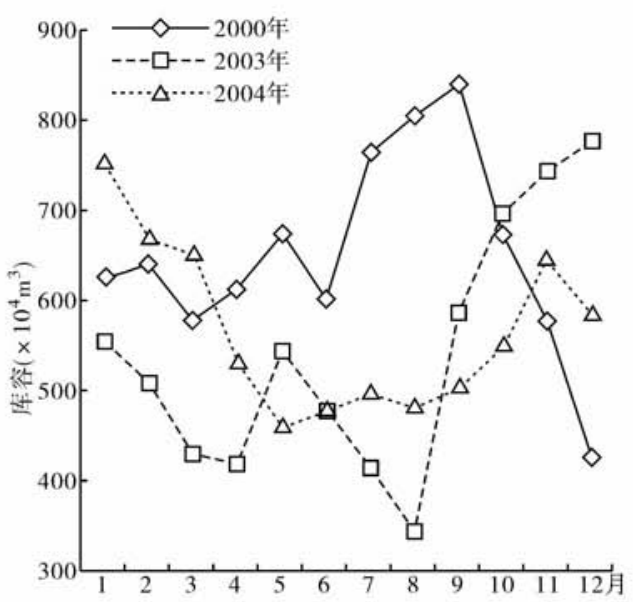

图 3 契爷石水库库容动态

Fig. 3 Water volume of Qiyeshi

Reservoir in 2003 and 2004

\section{2 水库的水质及其动态}

除 2003 年 7 月以外,水库 TN 浓度一直保持在较高水平, 大于 $0.7 \mathrm{mg} / \mathrm{L} 2003$ 年 12 月浓度最高, 为 2 $\mathrm{mg} / \mathrm{L}$. 水库 $\mathrm{TN}$ 浓度存在较为明显的季节变化 (表 1). 2004 年 2 月份水库 $\mathrm{TN}$ 浓度为 $1.33 \mathrm{mg} / \mathrm{L}$, 进人 4 月, 为丰水期的初期, 面源污染随降雨大量进人水库, 同时水库水量较少, TN 浓度上升, 达 $1.46 \mathrm{mg} / \mathrm{L} .6$ 月份开 始, 随着水库人库流量及降雨量增加, 水体营养盐浓度得到稀释, TN 浓度有所下降, 为 $1.39 \mathrm{mg} / \mathrm{L} .7$ 月和 8 月份人库流量均超 $200 \times 10^{4} \mathrm{~m}^{3}$, 水库的 $\mathrm{TN}$ 浓度达到最低值, 为 $0.71 \mathrm{mg} / \mathrm{L}$. 进人 12 月, 几乎没有人库流 量, $\mathrm{TN}$ 浓度达到最高, 为 $1.63 \mathrm{mg} / \mathrm{L}$. 组成上, $\mathrm{TN}$ 主要来自无机氮, 其中 $\mathrm{NO}_{3}-\mathrm{N}$ 占比例较高 ( $60 \%$ 以上), 最 高值出现在 2004 年 12 月,为 $1.27 \mathrm{mg} / \mathrm{L}$. 水库中 $\mathrm{NO}_{3}-\mathrm{N}$ 与 $\mathrm{NH}_{4}-\mathrm{N}$ 含量变化趋势与 $\mathrm{TN}$ 较为一致,枯水期的 浓度高于丰水期. 总体上, 水库 $\mathrm{TN}$ 浓度与人库流量存在较强的负相关 $\left(R^{2}=0.9687, P=0.008\right)$, 即调水人 库后水量增加会导致水体中 TN 浓度的下降.

TP 浓度范围为 $0.01-0.09 \mathrm{mg} / \mathrm{L}$, 绝大多数情况下, 无机磷低于检测限. 组成上, TP 主要为有机磷, TP 与叶绿素 a 浓度有显著的正相关. 在 2003 年的 7 月、2004 年 4 月、 8 月、10 月浓度较高, 最高值出现 2004 年 的 10 月, 这些月份的叶绿素 a 浓度和生物量也较高. 在水温较低 2 月和 12 月, TP 浓度有所下降. 与 TN 浓 度的动态相比, TP 有相反的动态变化, 反映出氮和磷污染的来源不同.

表 1 契爷石水库营养盐及叶绿素动态 (单位: $\mathrm{mg} / \mathrm{L}$ ) *

Tab. 1 Nutrient concentrations in Qiyeshi Reservoir in 2003 and 2004, in mg/L

\begin{tabular}{|c|c|c|c|c|c|c|c|c|c|}
\hline \multirow{2}{*}{ 时间 } & \multicolumn{3}{|c|}{2003 年 } & \multicolumn{6}{|c|}{2004 年 } \\
\hline & 7月 & 9月 & 12 月 & 2 月 & 4 月 & 6月 & 8 月 & 10 月 & 12 月 \\
\hline $\mathrm{NO}_{3}-\mathrm{N}(\mathrm{mg} / \mathrm{L})$ & 0.07 & 0.38 & 0.87 & 0.82 & 0.47 & 0.59 & 0.15 & 0.16 & 1.27 \\
\hline $\mathrm{NO}_{2}-\mathrm{N}(\mathrm{mg} / \mathrm{L})$ & - & 0.02 & 0.04 & 0.01 & 0.02 & 0.02 & 0.01 & 0.01 & 0.02 \\
\hline $\mathrm{NH}_{4}-\mathrm{N}(\mathrm{mg} / \mathrm{L})$ & 0.01 & 0.34 & 0.17 & 0.13 & 0.12 & 0.09 & 0.09 & 0.28 & 0.04 \\
\hline $\mathrm{TN}(\mathrm{mg} / \mathrm{L})$ & 0.11 & 1.47 & 2 & 1.33 & 1.46 & 1.29 & 0.71 & 0.78 & 1.6 \\
\hline $\mathrm{PO}_{4}-\mathrm{P}(\mathrm{mg} / \mathrm{L})$ & 0.02 & 0.01 & - & - & - & - & - & - & - \\
\hline $\mathrm{TP}(\mathrm{mg} / \mathrm{L})$ & 0.05 & 0.03 & 0.02 & 0.01 & 0.05 & 0.01 & 0.06 & 0.09 & 0.03 \\
\hline Chl. $a\left(\mathrm{mg} / \mathrm{m}^{3}\right)$ & 27.84 & 14.62 & 10.96 & 5.51 & 15.53 & 8.65 & 30.08 & 44.03 & 9.43 \\
\hline
\end{tabular}

* - 表示没有检测出.

叶绿素 a 浓度在 5.0-44 mg/m $\mathrm{m}^{3}$ 之间, 最低值出现在 2 月份, 最高值出现在 2004 年 10 月 (表 1). 丰水期 
及枯水期的初期, 叶绿素 a 浓度较高, 由水温和水滞留时间共同决定. 在 2003 年, 叶绿素 a 浓度在 7 月较 高, 为 $27.8 \mathrm{mg} / \mathrm{m}^{3}, 9$ 月, 仍有较高的降雨量, 叶绿素 $\mathrm{a}$ 浓度较低. 在 2004 年, 8 月后降水明显减少, 10 月的叶 绿素 a 浓度最高, 达 $44 \mathrm{mg} / \mathrm{m}^{3}$.

采用包括 Chl. a、TN、TP 和 SD 在内的相关加权综合营养状态指数来评价水库调水后的营养状态 ${ }^{[10]}$, 其 中 TN 及 TP 与 SD 及 Chl. a 之间的经验公式来自对广东省 20 座大型水库的调查结果 ${ }^{[12]}$. 水库综合营养状 态指数为 $45-55$ (表 2 ), 表明水库仍处于富营养水平,丰水期营养水平略高于枯水期.

表 22003 年和 2004 年契爷石水库综合营养状态指数

Tab. 2 Trophic state indices of Qiyeshi Reservoir in 2003 and 2004

\begin{tabular}{|c|c|c|c|c|c|c|c|c|c|}
\hline \multirow{2}{*}{ 时间 } & \multicolumn{3}{|c|}{2003 年 } & \multicolumn{6}{|c|}{2004 年 } \\
\hline & 7月 & 9 月 & 12 月 & 2 月 & 4 月 & 6 月 & 8 月 & 10 月 & 12 月 \\
\hline TSI & 51 & 50 & 49 & 45 & 50 & 47 & 55 & 55 & 46 \\
\hline
\end{tabular}

\section{3 浮游植物群落结构与组成}

表 3 给出了契爷石水库浮游植物的种类组成, 2 年的调查中共检出浮游植物 86 种,绿藻的种类较多, 其次是蓝藻,再次是硅藻. 丰水期的种类数少于枯水期,2003 年 7 月种类最少,为 41 种;2004 年 12 月种类 最多, 达 72 种. 种类变化最大的是绿藻类, 蓝藻和硅藻的组成相对稳定. 绿藻门中检测到的种类较多, 其中 微小四角藻 (Tetraedron minimum) 和双对栅藻 (Scenedesmus bijugatus) 常年可见, 但无明显的数量优势. 蓝藻 门的铜绿微囊藻 (Microcystis sp.) 、针状蓝纤维藻 (Dactylococcopsis acicularis)、湖生束丝藻 (Aphanizomenon sp. ) 、假鱼腥藻 (Pseudoanabaena sp.) 和粘球藻 (Gloeocapsa sp.) 全年可见. 其中, 假鱼腥藻全年数量较高, 6 月 -10 月针状蓝纤维藻数量较高. 硅藻门中颗粒直链藻 (Melosira granulata)、梅尼小环藻 (Cyclotella sp.) 、 短小曲壳藻 (Achnanthes exigua) 和针杆藻 (Synedra sp.) ) 为常见藻种. 甲藻门以多甲藻 (Peridinium pusillum) 和薄甲藻 (Glenodinum pulvisculus) 为常见藻种. 裸藻以桃形扁裸藻 (Phacus stokesii) 和囊裸藻 (Trachelomonas sp. ) 为常见澡种.

表 $32003-2004$ 年契爷石水库浮游植物种类组成

Tab. 3 Species composition of phytoplankton in Qiyeshi Reservoir in 2003 and 2004

\begin{tabular}{|c|c|c|c|c|c|c|c|c|c|c|}
\hline \multirow{2}{*}{ 种类 } & \multicolumn{3}{|c|}{2003 年 } & \multicolumn{6}{|c|}{2004 年 } & \multirow{2}{*}{ 总计 } \\
\hline & 7月 & 9月 & 12 月 & 2 月 & 4月 & 6月 & 8 月 & 10 月 & 12 月 & \\
\hline 蓝藻门( Cyanophyta) & 8 & 11 & 12 & 10 & 12 & 9 & 13 & 12 & 14 & 15 \\
\hline 绿藻门(Chlorophyta) & 21 & 34 & 32 & 42 & 37 & 25 & 25 & 38 & 38 & 46 \\
\hline 硅藻门( Bacillariophyta) & 10 & 12 & 8 & 11 & 8 & 8 & 11 & 12 & 13 & 16 \\
\hline 甲澡门(Pyrrophyta) & 0 & 3 & 2 & 2 & 4 & 1 & 3 & 3 & 4 & 3 \\
\hline 隐藻门 (Cryptophyta) & 0 & 1 & 1 & 0 & 1 & 0 & 1 & 1 & 1 & 1 \\
\hline 金藻门(Chrysophyta) & 0 & 1 & 0 & 1 & 0 & 0 & 1 & 0 & 1 & 2 \\
\hline 裸藻门(Euglenophyta) & 2 & 1 & 2 & 2 & 3 & 1 & 1 & 1 & 1 & 3 \\
\hline 共计 & 41 & 63 & 57 & 68 & 65 & 44 & 55 & 67 & 72 & 86 \\
\hline
\end{tabular}

\section{4 浮游植物密度}

2 年 9 次采样中的浮游植物细胞密度有很大的波动,枯水期密度要显著低于丰水期 (图 4). 最低密度出 现在 2004 年 2 月, 为 $463 \times 10^{4}$ cells $/ \mathrm{L}$; 最高密度出现在 2003 年 7 月, 达 $14296 \times 10^{4}$ cells $/ \mathrm{L}$. 丰水期蓝藻细 胞密度很高, 丰水期的后期以及枯水期, 蓝藻的比例下降, 硅藻占较大比例. 2004 年 2 月, 蓝藻密度很低 $\left(200 \times 10^{4}\right.$ cells $/ \mathrm{L}$ 左右 $), 4$ 月份蓝藻密度迅速增加 $\left(5000 \times 10^{4}\right.$ cells $/ \mathrm{L}$ 左右 $), 6$ 月份蓝藻密度降低, 8 月份 再次迅速增加, 达到最高值 $\left(11422 \times 10^{4}\right.$ cells/L 左右 $)$. 进人 10 月后. 数量急剧降低, 12 月密度较低 $(250 \times$ 
$10^{4} \mathrm{cells} / \mathrm{L}$ 左右). 绿澡在 8 月份密度最高, 约 $500 \times 10^{4} \mathrm{cells} / \mathrm{L}, 2$ 月、12 月密度较低, 约 $100 \times 10^{4} \mathrm{cells} / \mathrm{L}$. 硅 藻门的曲壳藻和针杆藻在 4-8 月密度较高, 硅藻门在丰水期超过绿藻.

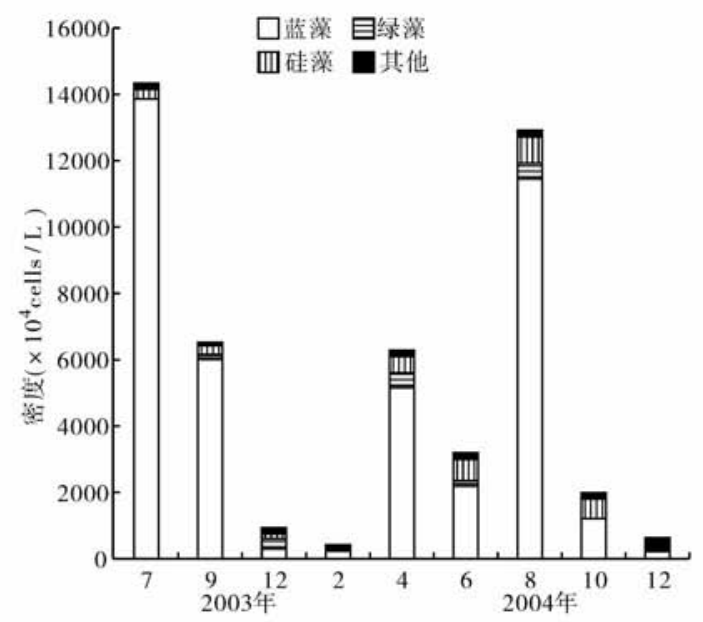

图 $42003-2004$ 年浮游植物密度变化

Fig. 4 Dynamics of phytoplankton abundance

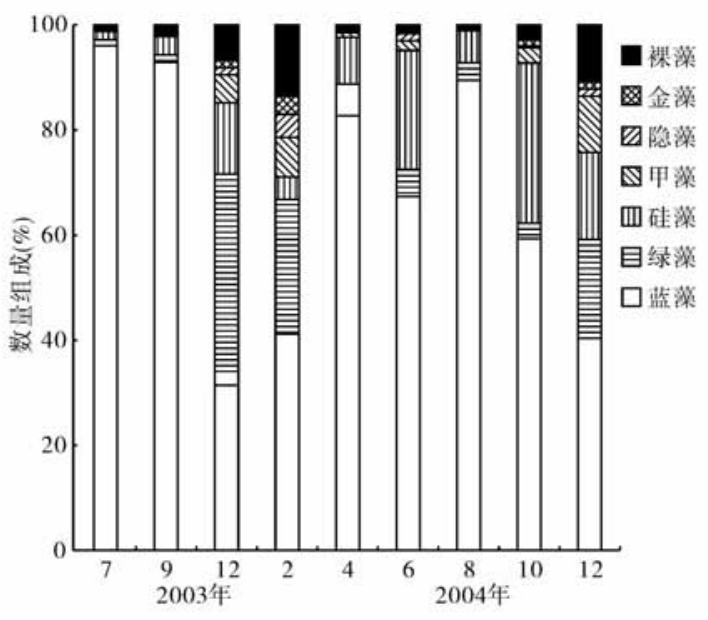

图 5 2003-2004 年浮游植物数量组成变化

Fig. 5 Dynamics of phytoplankton composition

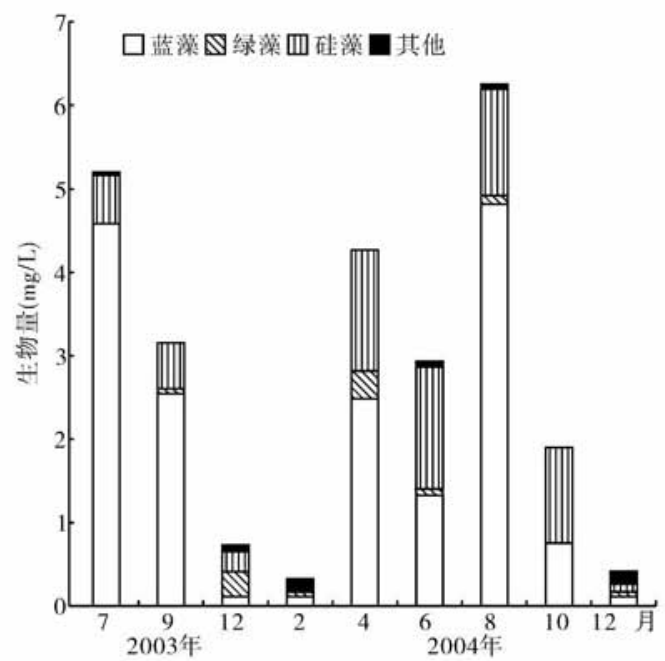

图 62003 年和 2004 年契爷石水库浮游 植物生物量的分布

Fig. 6 Biomass distribution of phytoplankton in 2003 and 2004

从契爷石水库不同时期的浮游植物密度来看, 全年都 是蓝藻占优势 (图 5). 2004 年采样中, 蓝藻密度比例在 4 -8 月较高 ( $65 \%$ 以上), 进人枯水期后, 蓝藻密度比例有 所下降, 其中, 2 月最低, 占 $405 \%$ 以下. 绿藻密度比例在 2 月最高, 占 $20 \%$ 以上. $4-8$ 月较低( 低于 $5 \%$ ). 硅藻密度 比例在 10 月 -12 月较高( $10 \%$ 以上), 8 月最低. 裸藻密度 比例在 2 月和 12 月较高 ( $10 \%$ 以上), 其余月份较低(低于 $3 \%)$.

\section{5 浮游植物生物量}

契爷石水库浮游植物的总生物量范围为 $0.31-6.24$ $\mathrm{mg} / \mathrm{L}$ (图 6), 且丰水期生物量明显高于枯水期. 2003 年, 7 月的生物量较高, 为 $5.19 \mathrm{mg} / \mathrm{L}, 9$ 月有明显下降, 为 3.17 $\mathrm{mg} / \mathrm{L}, 12$ 月最低, 为 $0.71 \mathrm{mg} / \mathrm{L} .2004$ 年 12 月和 2 月最低, 丰水期初期的 4 月生物量明显上升, 6 月因调水人库生物 量有所下降, 8 月最高, 达 $6.24 \mathrm{mg} / \mathrm{L}, 10$ 月因大量调水人 库生物量急剧下降.

2003 年丰水期, 浮游植物的生物量主要由蓝藻门假 鱼腥藻 (占总量的 $45 \%$ ) 和针状蓝纤维藻的生物量 (占总 量的 $30 \%$ ) 组成, 其它藻类对浮游植物生物量的贡献较 小. 硅藻生物总量在 7、9 和 12 月比较稳定, 约为 $0.5 \mathrm{mg} / \mathrm{L} .2004$ 年 4-8 月, 蓝藻生物量占优势, 均超过 1.3 $\mathrm{mg} / \mathrm{L}, 10$ 月硅藻成为主要优势类群. 硅藻生物量在 2 月和 12 月较低, 但在 $4-10$ 月的生物量接近 $1.5 \mathrm{mg} /$ $\mathrm{L}$, 且较为稳定. 其它澡类生物量较低 (低于 $0.3 \mathrm{mg} / \mathrm{L}$ ).

\section{6 浮游植物优势种类}

2003 年和 2004 年 9 次采样中的主要优势种有蓝藻中的假鱼腥藻和针状蓝纤维藻,硅藻中的短小曲壳 藻、针杆藻、梅尼小环藻和变异直链藻, 以及绿藻中的四尾棚藻. 其中假鱼腥藻、针状蓝纤维藻、短小曲壳藻 
和针杆藻有较高的优势度, 它们在丰水期的优势更为明显 (表 4).

表 $42003 、 2004$ 年水库浮游植物优势种生物量分布 *

Tab. 4 Distributions of biomass for the dominated species

\begin{tabular}{|c|c|c|c|c|c|c|c|c|c|}
\hline \multirow{2}{*}{ 主要优势种类 } & \multicolumn{3}{|c|}{2003 年 } & \multicolumn{6}{|c|}{2004 年 } \\
\hline & 7 月 & 9 月 & 12 月 & 12 月 & 2 月 & 4月 & 6 月 & 8 月 & 10 月 \\
\hline 假鱼腥藻 & $\underline{3.790}$ & $\underline{1.343}$ & 0.060 & 0.015 & $\underline{0.865}$ & 0.059 & 2.352 & 0.128 & 0.055 \\
\hline 针状蓝纤维藻 & $\underline{0.577}$ & $\underline{0.412}$ & 0.050 & 0.033 & $\underline{1.319}$ & $\underline{0.661}$ & $\underline{2.041}$ & $\underline{0.448}$ & 0.039 \\
\hline 四尾相藻 & 0.027 & 0.040 & 0.147 & 0.024 & 0.091 & 0 & 0.0150 & 0.033 & \\
\hline 微小四角藻 & 0 & 0 & 0.071 & 0.055 & 0.171 & 0 & 0 & 0 & 0.045 \\
\hline 梅尼小环藻 & $\underline{0.362}$ & $\underline{0.475}$ & 0.061 & 0.023 & 0.058 & 0 & 0.025 & 0.188 & 0.037 \\
\hline 短小曲壳澡 & 0.209 & 0.089 & 0.058 & 0 & 1.271 & $\underline{0.984}$ & 0.289 & $\underline{0.480}$ & 0.040 \\
\hline 变异直链藻 & 0 & 0 & $\underline{0.138}$ & 0 & 0 & 0 & 0 & 0 & 0 \\
\hline 尖针杆藻 & 0 & 0 & 0.044 & 0.010 & 0.150 & $\underline{0.532}$ & $\underline{0.990}$ & 0.462 & 0.021 \\
\hline 共占总生物量的比例 & $95.7 \%$ & $74.4 \%$ & $88.1 \%$ & $51.9 \%$ & $91.4 \%$ & $76.9 \%$ & $91.5 \%$ & $89.5 \%$ & $66.4 \%$ \\
\hline
\end{tabular}

*下划线对应藻种为当月主要优势种

\section{3 讨论}

\section{1 调水后水库水文特征的变化}

调水前水库来水主要来自降雨,水库水文动态主要受降雨的影响 ${ }^{[13]}$. 受热带季风的影响,降雨主要集 中在丰水期 4-9 月. 2000 年 (调水人库前), 人库总流量 $(y)$ 与降雨量 $(x)$ 呈明显的正相关 $(y=0.9729 x-$ $\left.10.799, R^{2}=0.933\right)$, 但调水后, 这种相关性显著下降 $\left(2003: y=0.6134 x+103.9, R^{2}=06.298 ; 2004: y=\right.$ $\left.0.5982 x+75.816, R^{2}=0.4061\right)$.

由于该水库为中型水库, 且流域面积小, 来水量不大, 调水前水库水力滞留时间相对稳定, 约为 $100 \mathrm{~d}$. 调水人库后, 水库供水能力提高, 改善了枯水期的供水条件. 调水主要发生在枯水期,提高了枯水期的水库 水量, 水体的滞留时间在枯水期有进一步的增加, 平均超过 $150 \mathrm{~d}$. 由于丰水期的供水量大, 在降雨人库流量 不足的情况下,2004 年的丰水期也调水人库,导致丰水期的滞留时间减少,远低于 $100 \mathrm{~d}$. 调水改变了水库的 水文特征 ${ }^{[14]}$, 水滞留时间的季节变化更为明显 (图 7). 这种由调水人库引起的人库流量的变化和供水量的 增加将直接影响水库的水质和浮游植物群落的结构.

\section{2 调水后水库水质的动态特征}

调水前的 2000 年,水库 TN 浓度一直保持较高水平,在 $0.96-2.0 \mathrm{mg} / \mathrm{L}$ 之间. 调水后, 2003 年 7 月有显 著的下降,但丰水期末和枯水期又回到了调水前水平,2004 年 6 月 - 8 月有所下降,可能与 $5 、 6$ 月连续调水 人库有关. TN 主要来自面源污染和点源污染, 面源污染与降雨有大的关系, 特别是丰水期初期, 人库 TN 较 多,点源污染在枯水期较为明显; 通常水库 TN 浓度与人库流量存在较强的负相关 ${ }^{[15,16]}$. 与调水前的同期相 比, 调水后, 尽管枯水期调水人库量大,枯水期水库 TN 的浓度并没有下降,这说明目前水库 TN 的来源可能 更多依赖底泥的再悬浮,特别是在水温较低的时期 ${ }^{[17]}$.

调水前,水库在丰水期和枯水期的 TP 浓度均超过 $0.1 \mathrm{mg} / \mathrm{L}$, 其中无机磷占近 $50 \%$. 调水后 TP 的浓度 下降, 只在 2004 年 10 月相对较高 $(0.09 \mathrm{mg} / \mathrm{L})$, 多数情况下不超过 $0.05 \mathrm{mg} / \mathrm{L}$, 且无机磷低于检测限; 在组 成上, TP 主要为有机磷. 因此, 调水人库明显减少了水体的磷浓度.

调水前,枯水期的叶绿素 a 浓度要高于丰水期. 调水后,2003 年水体的叶绿素浓度有明显的增加,但枯 水期下降;2004 年 6 月因调水, 叶绿素浓度相对较低,停止调水后的 8 月和 10 月显著增加,受大量调水的影 响, 12 月有明显下降. 因此调水对浮游植物叶绿素浓度影响较为复杂 ${ }^{[18]}$. 在调水人库初期, 水库水量增加, 大大稀释了水体藻类的密度, 而由于水体透明度的增加, 停止调水后浮游植物的密度大幅度上升, 这在丰水 期特别明显. 
调水前, 枯水期营养水平稍高于丰水期 ${ }^{[19]}$. 这与枯水期库容较小、营养盐浓度较高有关. 调水后, 丰水 期水库营养水平略高于枯水期. 主要是因为枯水期调水量较大, 稀释了浮游植物密度, 叶绿素 a 浓度降低.

\section{3 调水前后浮游植物群落特征比较}

调水前, 2 次采样中浮游植物的种类分别为 22 种和 28 种, 蓝藻中假鱼腥藻和蓝纤维藻是主要优势种. 调水后, 浮游植物种类数量大大增加, 每次采样不少于 45 种, 新增种类主要为绿藻门, 有多芒藻、微茫藻、粘 四集藻、空星藻及鞘藻, 枯水期的增加更为明显. 就优势种而言, 假鱼腥藻和针状蓝纤维藻仍为主要优势种, 但硅藻中的短小曲壳藻、尖针杆藻成为新的优势种. 调水前裸藻中的桃形扁裸藻和囊裸藻有较高的丰度, 调 水后这些种类的数量大为减少.

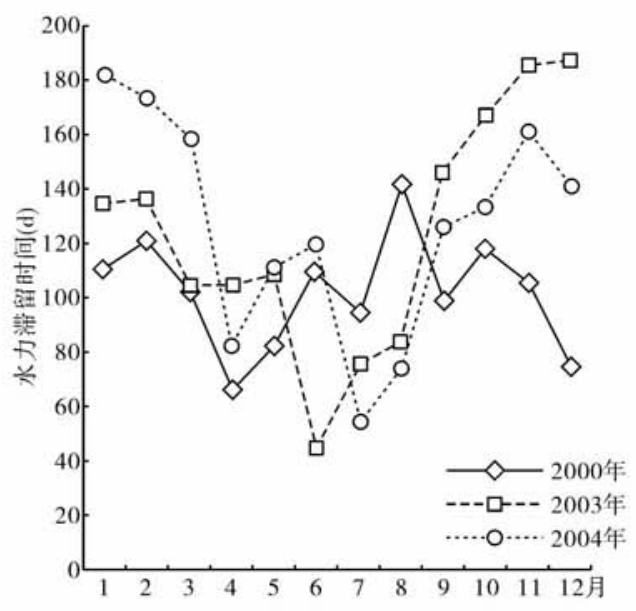

图 72000 年, 2003 年及 2004 年水库水 滞留时间动态变化

Fig. 7 Variation in hydraulic retention time in 2000,2003 and 2004

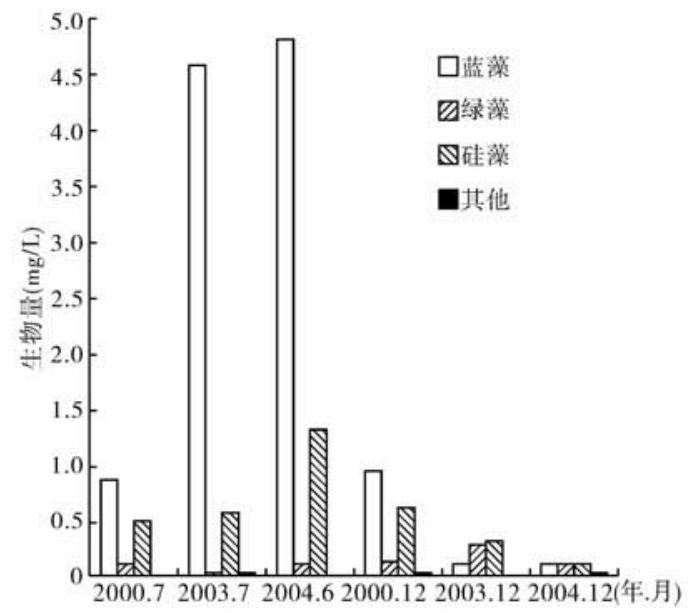

图 82000 年、2003 年及 2004 年丰水期、枯水期 生物量动态变化

Fig. 8 Dynamics of biomass in flood seasons and dry seasons in 2000, 2003 and 2004

与 2000 年相比, 浮游植物的生物量在丰水期有了明显的增加, 特别是蓝藻的生物量增加, 而枯水期的 生物量则有所下降 (图 8), 这种变化与调水模式密切相关. 丰水期的少量调水增加了水体的透明度, 有利于 浮游植物在高温下的光合生产 ${ }^{[20,21]}$, 丰水期末往往是浮游植物的生物量最高的时期. 在枯水期的中后期, 调水人库后透明度增加但由于水温低难以支持浮游植物的光合生产. 如果水体营养盐浓度不能明显下降, 这种透明度改善可能会提高丰水期蓝藻水华的风险.

\section{4 结论}

契爷石水库作为一座中型水库,由于库容小,水文条件容易受调水的影响,而水文条件是影响契爷石水 库水质和浮游植物群落结构变化的主要因子. 在枯水期中后期, 大量调水使得水库水温降低和水体混合强 度增加, $\mathrm{TN}$ 浓度增加; 调水人库稀释了水体浮游植物的密度, 浮游植物密度降低. 同时, 由于水体不稳定和 水温的降低, 不利于浮游植物的累积, 使得枯水期浮游植物生物量降低, 没有形成绝对优势种. 在丰水期, 降 雨量较多, 调水水量较小. 降雨形成的地表径流是外源营养盐输人的主要途径之一, TP 浓度略高于枯水期. 由于在枯水期的调水改善了水体的透明度, 进人丰水期后, 水温上升有利于蓝藻成为优势类群. 因此, 调清 水人库作为常见的水库水质改善方法, 在短期内改善水库水质、降低富营养化程度也是困难的, 要达到改善 水质的目的,需加强对水库生态系统和调水调度的管理.

致谢: 契爷石水库管理所的有关人员协助采样并提供了水文数据, 暨南大学水生生物研究所水库组的老师、 同学协助完成营养盐浓度测定及浮游植物定量分析,在此一并感谢. 


\section{5 参考文献}

[1] 韩博平,李 铁,林旭钿. 广东省大中型水库富营养化现状与防治对策研究. 北京: 科学出版社, 2003: $29-35$.

[2] Moss B, Balls H, Irvine $\mathrm{K}$ et al. Restoration of two lowland lakes by isolation from nutrient-rich water sources with and without removal of sediment. J Appl Ecol, 1986, 23: 391 - 414.

[3] Kawara 0 \& Yura E. A study on the role of hydraulic retention time in eutrophication of the Asahi River Dam reservoir. Water Science and Technology, 1998, 37(2) :245 - 252.

[4] Mortimer C H. Chemical exchanges between sediments and water in the great Lakes-speculations on probable regulatory mechanisms. Limnol Oceanogr, 1971, 16: 387 - 404 .

[5] Weston $\mathrm{H}$. Release rates and potential fates of nitrogen and phosphorus from sediments in a eutrophic reservoir. Freshwater Biology, 2005, 13: $301-322$.

[6] Hamilton D P \& Schladow S G. Controlling the indirect effects of flow diversions on water quality in an Australian reservoir. Environment International, 1995, 21(5) : $583-590$, .

[7] 林秋奇, 胡 韧, 韩博平. 广东省大平型水库富营养化现状与浮游生物的响应. 生态学报, 2003, 23 (6) $: 73-81$.

[8] 林少君, 贺立静, 韩博平. Comparison and improvement on the extraction method for chlorophyll a in phytoplankton. 生态科学, 2005, 21(2): $147-151$.

[9] 章宗涉,黄祥飞. 溶水浮游生物研究方法. 北京:科学出版社,1991.

[10] 金相灿，屠清瑛. 湖泊富营养调查规范,北京:中国环境科学出版社,1990.

[11] 孙 军, 刘东艳, 钱树本. Study on phytoplankton biomass I. Phytoplankton measurement biomass from cell volume or plasma volume. 海洋学报, 1999, 21(2) : 75-85.

[12] Lin Q Q, Han B P Li T. Reservoir water supply and reservoir eutrophication in Guangdong Province (south china) in international Lake Environment Committee (ed). Proceedings of $9^{\text {th }}$ international Conference on the conservation and management of Lakes. Shiga, Japan; Shiga prefectual Government, 3(1).

[13] Geraldes A M \& Boavida M J. Limnological variations of a reservoir during two successive years: One wet, another dry. Lakes \& Reservoirs: Research and Management, 2004, 9: 143 - 152.

[14] Coulter GW, Davies J \& Pickmere S. Seasonal limnological change and phytoplankton production in Ohakuri. A hydro-electric lake on the Waikato River. Freshwater Res, 1983, 17: $169-183$.

[15] Jennifer. A. Spatial and seasonal variation in nutrient excretion by benthic invertebrates in a eutrophic reservoir. Freshwater Biol, 2002, 47 : $107-121$.

[16] Rahman A K M \& Bakri D A. Limnological characteristics, eutrophication and cyanobacterial blooms in an inland reservoir, Australia. Lakes \& Reservoirs: Research and Management, 2005, 10: 211 - 220.

[17] Arfi R \& Cecchi P. Effect of wind and density current on vertical mixing in a West African lake. Symposium for European. Freshwater Sciences, 2001, 2: 8-12.

[18] Arfi R. The effects of climate and hydrology on the trophic status of Selingue Reservoir, Mali, West Africa. Lakes \& Reservoirs: Research and Management, 2003, 8: 247 - 257.

[19] 董丽华,胡 㓞,林秋奇. 典型富营养型水库浮游生物的分析. 生态科学, 2002, 21(2): $147-151$.

[20] Cleber C F \& Giani A. Seasonal variation in the diversity and species richness of phytoplankton in a tropical eutrophic reservoir. Hydrobiologia, 2001, 445: $165-174$.

[21] Nogueria M G. Phytoplankton composition, dominance and abundance as indicators of environmental compartmentalization in Jurumirim Reservoir(Paranapanema River), Sao Pauo, Brazil. Hydrobiologia, 2000, 431 : $115-128$. 